\title{
INCIDENCE OF CONGENITAL DEFECTS IN SOUTH
}

\author{
WALES, 1964-6
}

\author{
I. D. G. RICHARDS ${ }^{1}$ AND C. R. LOWE \\ Department of Social and Occupational Medicine, Welsh National School of Medicine, Cardiff
}

Since Hale's observation in 1933 that sows on a diet deficient in vitamin A produce piglets without eyeballs, very many physical and chemical agents have been shown to be teratogenic in the animal laboratory (excess of various vitamins as well as vitamin deficiencies, hypoxia, hypothermia, ionizing radiations, and a wide range of chemicals, including some that are commonly prescribed in medical practice, e.g., insulin, cortisone, the hypoglycaemic sulphonamides, etc.). The search by epidemiological methods for environmental components in the aetiology of human malformations has been less rewarding. There is good evidence that environmental influences are involved, for the incidence of various defects shows geographical, secular, and seasonal fluctuations and social class, maternal age, and parity differences. So far, however, very few specific agents have been firmly incriminated (syphilis, rubella, toxoplasmosis, ionizing radiations, aminopterin, thalidomide) and it now seems likely that, although environmental influences are undoubtedly important, they will prove to be much more subtle and much less accessible to control than was at one time hoped.

Nevertheless, there is still a place for large-scale surveys of all the malformations arising in defined populations. By uncovering differences in the incidence of specific defects in relation to social, geographical, temporal, and biological variables, they may provide aetiological clues, and by establishing registers of affected infants they can be used as the starting point for cohort studies of the diagnostic, therapeutic, social, educational, and, eventually, employment needs of survivors. In England two such studies have been in progress for some time, one in Birmingham since 1950 (Leck, Record, McKeown, and Edwards, 1968), the other in Liverpool since 1960 (Smithells, 1962). Both of these surveys are concerned with highly industrialized and geographically compact communities. In the belief that there was a need for a comprehensive survey of the incidence of malformations in a larger area with a more varied

1 Present address: Social Paediatric Research Group, 23 Montrose Street, Glasgow C.1 population, we initiated on 1 January 1964 from the Department of Social and Occupational Medicine in the Welsh National School of Medicine a threeyear study of all the congenital defects occurring in the birth population of South Wales, with its coal mining valleys, steel towns, other urban communities, and agricultural districts.

In this first paper we define the birth population we are investigating, describe how our data were collected, and present a preliminary report on the incidence of congenital defects in South Wales for the three years covered by our survey.

\section{The Birth Population}

The area under survey consists of the counties of Glamorgan and Monmouthshire in South Wales and of the four county boroughs within their boundaries (Cardiff, Swansea, Merthyr Tydfil, and Newport). At the 1961 census the total population of the area was $1,671,517$. Data have been collected about all the infants $(92,982)$ born to women residents in the survey area for the three years beginning 1 January 1964 and ending 31 December 1966.

The medical officers of health of the six major local authorities in the area redesigned their birth notification cards to provide comparable data on the reproductive history of mothers, the occupation of fathers, and the birth weight, duration of gestation, and birth order of infants. Notification cards were forwarded to the Department of Social and Occupational Medicine at regular intervals and the data from them were transferred to coding sheets from which punch cards were prepared.

\section{Ascertainment of Congenital Defects}

Data about the congenital defects found in the birth population of the survey area were derived from four sources:

(1) Birth notification cards: any congenital defects noticed at or shortly after birth were reported on the birth notification card by the person in attendance at the birth.

(2) Congenital defect notification forms: pads of forms for notification to the Department of 
Social and Occupational Medicine of congenital defects observed in the birth population were distributed to all medical officers of health and all consultant obstetricians, paediatricians, pathologists, dermatologists, and orthopaedic, plastic, and ophthalmic surgeons in South Wales.

(3) Hospital records: most of the hospitals in the survey area keep diagnostic indices and from these the hospital records officers compiled lists of new cases of congenital defects which were forwarded to the Department every six months.

(4) Stillbirth and infant death registration: photostat copies of all stillbirths and infant death registrations in the survey population were provided by the Registrar General in monthly batches.

For each infant reported to have one or more congenital defects a separate coding sheet was made out and a separate punch card prepared. Each coding sheet and punch card recorded all the relevant birth notification data and additional information about the nature of the congenital defect or defects and the sources of ascertainment. All the records relating to a particular malformed infant are kept together in a separate envelope filed in birth-date order under the area of the mother's residence at the time of the birth.

\section{InCIDENCE of CONGENITAL Defects}

For a number of reasons reports on the incidence of congenital defects are peculiarly difficult to interpret and are, therefore, particularly difficult to compare. The principle sources of confusion are multiple pregnancies, multiple defects, completeness of ascertainment, and taxonomy. It is not always clear whether multiple pregnancies have been included (and if they have, whether the related mothers are represented more than once in the denominators of the rates). It is not always clear whether the rates relate to malformed infants or to defects (many malformed infants have more than one defect). It is often difficult to estimate and sometimes even to guess how complete the ascertainment of defects in the birth population has been. And most confusing of all, it is by no means always clear what classification of defects has been used.

Over the three years of our investigation 92,982 infants were born to women who were resident in the defined area. Of those infants 90,921 were the outcome of singleton pregnancies and 2,061 of multiple pregnancies. In this paper we confine our attention to the singleton infants and we report the incidence of congenital defects as ascertained among them at the
TABLE I

INFANT MALFORMATION RATES PER 1,000 SINGLETONC BIRTHS IN SOUTH WALES, 1964-6

\begin{tabular}{|c|c|c|c|c|}
\hline & 1964 & 1965 & 1966 & $1964-6 \overrightarrow{\mathbb{D}}$ \\
\hline $\begin{array}{l}\text { No of singleton } \\
\text { births (liveborn } \\
\text { and stillborn) }\end{array}$ & 31,060 & 30,432 & 29,429 & $90,921 \stackrel{\text { ज़ }}{\stackrel{\bar{c}}{+}}$ \\
\hline $\begin{array}{l}\text { Related no. of } \\
\text { malformed infants }\end{array}$ & 1,108 & 1,088 & 1,046 & 3,242 을 \\
\hline $\begin{array}{l}\text { Infant malforma- } \\
\text { tion rates per } \\
1,000 \text { singleton } \\
\text { births }\end{array}$ & $35 \cdot 7$ & $35 \cdot 8$ & 35.5 & 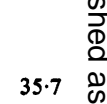 \\
\hline
\end{tabular}

second anniversary of their births. So defined, 3,24 $\overrightarrow{\mathrm{Q}}$ singleton infants were reported to have congenitas defects, a rate of 35.7 malformed infants per 1,000 total (live and stillborn) singleton births. The ratie varied very little from year to year (Table I).

The 3,242 malformed infants were reported t 8 have between them 4,444 specified defects; $23 \%$ of the infants had more than one defect and $1.5 \%$ had five or more defects (Table II). Four infants were eack reported to have nine defects.

Because we cast our net so widely, many of the malformed infants came to our notice from moret than one source. Indeed less than half of them $(47.4 \%)$ were ascertained only once, and $12 \Phi^{\circ} \%$ were ascertained four or more times (Table Ifi) Three of the malformed infants were caught in oum net seven times.

TABLE II

FREQUENCY OF REPORTED OCCURRENCE OF MULTIPLE DEFECTS

\begin{tabular}{|c|c|c|c|}
\hline $\begin{array}{c}\text { Reported No. } \\
\text { of Defects }\end{array}$ & $\begin{array}{l}\text { No. of } \\
\text { Infants }\end{array}$ & $\begin{array}{c}\text { Percentage } \\
\text { Distribution }\end{array}$ & $\begin{array}{l}\text { No. of } \\
\text { Defects }\end{array}$ \\
\hline $\begin{array}{r}1 \\
2 \\
3 \\
4 \\
5-9 \\
\end{array}$ & $\begin{array}{r}2,497 \\
491 \\
147 \\
59 \\
48 \\
\end{array}$ & $\begin{array}{r}77 \cdot 0 \\
15 \cdot 1 \\
4 \cdot 5 \\
1 \cdot 8 \\
1 \cdot 5 \\
\end{array}$ & $\begin{array}{r}, 497 \\
982 \\
441 \\
236 \\
288 \\
\end{array}$ \\
\hline Total & 3,242 & 100 & 4,444 \\
\hline
\end{tabular}

TABLE III

FREQUENCY OF ASCERTAINMENT OF MALFORMED ㅇำ INFANTS

\begin{tabular}{|c|c|c|}
\hline $\begin{array}{l}\text { No. of Times } \\
\text { Ascertained }\end{array}$ & No. of Infants & $\begin{array}{c}\text { Percentage } \\
\text { Distribution }\end{array}$ \\
\hline $\begin{array}{c}1 \\
2 \\
3 \\
4 \\
5-7\end{array}$ & $\begin{array}{r}1,536 \\
745 \\
549 \\
314 \\
98\end{array}$ & $\begin{array}{r}47 \cdot 4 \\
23 \cdot 0 \\
16.9 \\
9 \cdot 7 \\
3.0\end{array}$ \\
\hline Total & 3,242 & 100 \\
\hline
\end{tabular}


TABLE IV

SOURCE OF FIRST NOTIFICATION OF MAJOR GROUPS OF MALFORMATIONS

\begin{tabular}{|c|c|c|c|c|c|c|c|c|c|c|}
\hline Type of Malformation & $\begin{array}{l}\text { Birth } \\
\text { Notifica- } \\
\text { tion } \\
\text { Form }\end{array}$ & $\begin{array}{l}\text { Hos- } \\
\text { pital } \\
\text { Obste- } \\
\text { tric } \\
\text { Unit }\end{array}$ & $\begin{array}{c}\text { Paedia- } \\
\text { trician } \\
\text { outside } \\
\text { Obstetric } \\
\text { Unit }\end{array}$ & $\begin{array}{l}\text { Patho- } \\
\text { logist }\end{array}$ & $\begin{array}{l}\text { Other } \\
\text { Con- } \\
\text { sultant }\end{array}$ & M.O.H. & $\begin{array}{c}\text { Hos- } \\
\text { pital } \\
\text { Records }\end{array}$ & $\begin{array}{l}\text { Stillbirth } \\
\text { or Death } \\
\text { Regis- } \\
\text { tration }\end{array}$ & $\begin{array}{l}\text { Other } \\
\text { and } \\
\text { Un- } \\
\text { known }\end{array}$ & Total \\
\hline $\begin{array}{l}\text { Central nervous system } \\
\text { Heart and great vessels } \\
\text { Alimentary system } \\
\text { Limb and skeletal system }\end{array}$ & $\begin{array}{l}84 \cdot 5 \% \\
(628) \\
14 \cdot 1 \% \\
(56) \\
34 \cdot 7 \% \\
(198)\end{array}$ & $\begin{array}{l}6.2 \% \\
(46) \\
18.6 \% \\
(74) \\
9 \cdot 3 \% \\
(53)\end{array}$ & $\begin{array}{c}1.5 \% \\
(11) \\
18 \cdot 1 \% \\
(72) \\
30.1 \% \\
(172)\end{array}$ & $\begin{array}{r}0.7 \% \\
(5) \\
11 \cdot 3 \% \\
(45) \\
2 \cdot 1 \% \\
(12)\end{array}$ & $\begin{array}{c}0.0 \% \\
(0) \\
0.8 \% \\
(3) \\
3.2 \% \\
(18)\end{array}$ & $\begin{array}{c}2 \cdot 6 \% \\
(19) \\
12 \cdot 3 \% \\
(49) \\
4 \cdot 0 \% \\
(23)\end{array}$ & $\begin{array}{c}1.9 \% \\
(14) \\
9.0 \% \\
(36) \\
14.4 \% \\
(82)\end{array}$ & $\begin{array}{c}2 \cdot 0 \% \\
(15) \\
15.6 \% \\
(62) \\
2 \cdot 3 \% \\
(13)\end{array}$ & $\begin{array}{c}0.7 \% \\
(5) \\
0.3 \% \\
(1) \\
0.0 \% \\
(0)\end{array}$ & $\begin{array}{r}100 \% \\
(743) \\
100 \% \\
(398) \\
100 \% \\
(571)\end{array}$ \\
\hline Miscellaneous systems & $\begin{array}{l}44 \cdot 5 \% \\
(341) \\
36 \cdot 3 \% \\
(416)\end{array}$ & $\begin{array}{l}17.6 \% \\
(135) \\
20.8 \% \\
(238)\end{array}$ & $\begin{array}{l}2.0 \% \\
(15) \\
8.0 \% \\
(92)\end{array}$ & $\begin{array}{l}0.5 \% \\
(4) \\
2.6 \% \\
(30)\end{array}$ & $\begin{array}{l}16.4 \% \\
(126) \\
8.6 \% \\
(98)\end{array}$ & $\begin{array}{l}15 \cdot 1 \% \\
(116) \\
18 \cdot 2 \% \\
(209)\end{array}$ & $\begin{array}{l}2.9 \% \\
(22) \\
3.5 \% \\
(40)\end{array}$ & $\begin{array}{l}0.4 \% \\
(3)^{\circ} \\
1.7 \% \\
(20)\end{array}$ & $\begin{array}{c}0.5 \% \\
(4) \\
0.3 \% \\
(3)\end{array}$ & $\begin{array}{c}100 \% \\
(766) \\
100 \% \\
(1146)\end{array}$ \\
\hline
\end{tabular}

${ }^{1}$ The grand total is 382 more than the number of infants, i.e., at most, 382 infants had malformations of more than one system.

In Table IV the source of the first notification of certain broad groups of malformations is shown. It underlines the point made by Leck and Record (1963) that birth notification can by itself provide only a very incomplete picture of the incidence of defects in a birth population. In fact, except for infants having malformations of the central nervous system (most of which are immediately obvious), incidence rates based on notification data are grossly deficient (for obvious reasons only $14 \%$ of the infants having cardiovascular defects were ascertained from the birth notification forms). The most effective combination of sources of information varies from group to group (and within the groups from defect to defect), so reasonable completeness of ascertainment can be assumed only if all possible sources of information have been tapped. However, it is perhaps worth reporting that a combination of birth notification and notification from obstetric units uncovered $95 \%$ of all the infants ascertained to have anencephalus and/or spina bifida and $88 \%$ of all the infants ascertained to have cleft lip and/or palate.

\section{TABLE V}

INCIDENCE OF MAJOR GROUPS OF MALFORMATIONS (rate per 1,000 singleton births in 1964, 1965, and 1966)

\begin{tabular}{|c|c|c|c|c|}
\hline Type of Malformation & 1964 & 1965 & 1966 & $1964-6$ \\
\hline Central nervous system & $\begin{array}{c}7 \cdot 41 \\
(230)\end{array}$ & $\begin{array}{c}8 \cdot 24 \\
(251)\end{array}$ & $\begin{array}{c}8.90 \\
(262)\end{array}$ & $\begin{array}{c}8 \cdot 17 \\
(743)\end{array}$ \\
\hline Heart and great vessels & $\begin{array}{c}4 \cdot 67 \\
(145)\end{array}$ & $\begin{array}{c}4 \cdot 60 \\
(140)\end{array}$ & $\begin{array}{c}3 \cdot 84 \\
(113)\end{array}$ & $\begin{array}{c}4 \cdot 38 \\
(398)\end{array}$ \\
\hline Alimentary system & $\begin{array}{c}6 \cdot 60 \\
(205)\end{array}$ & $\begin{array}{l}6 \cdot 57 \\
(200)\end{array}$ & $\begin{array}{r}5.64 \\
(166)\end{array}$ & $\begin{array}{c}6 \cdot 28 \\
(571)\end{array}$ \\
\hline $\begin{array}{l}\text { Limb and skeletal sys- } \\
\text { tems (without spina } \\
\text { bifida) }\end{array}$ & $\begin{array}{c}8 \cdot 66 \\
(269)\end{array}$ & $\begin{array}{l}8 \cdot 38 \\
(255)\end{array}$ & $\begin{array}{c}8 \cdot 22 \\
(242)\end{array}$ & $\begin{array}{r}8 \cdot 42 \\
(766)\end{array}$ \\
\hline Miscellaneous systems & $\begin{array}{l}12 \cdot 78 \\
(397)\end{array}$ & $\begin{array}{l}11.99 \\
(365)\end{array}$ & $\begin{array}{l}13 \cdot 05 \\
(384)\end{array}$ & $\begin{array}{r}12 \cdot 60 \\
(1,146)\end{array}$ \\
\hline
\end{tabular}

Because of the intensity of our search, we are fairly certain that our ascertainment of the major congenital defects is almost complete, but we have no way of testing this assumption. Ascertainment of the broad groups of defects varied little from year to year (Table V), which suggests that there was no serious flagging of enthusiasm among the very many people who helped by notifying to us all defects coming to their attention.

In Table VI we show the ascertained incidence of

\section{TABLE VI}

INCIDENCE OF CERTAIN TYPES OF MALFORMATIONS (rate per 1,000 singleton births, 1964-6)

\begin{tabular}{|c|c|c|}
\hline Type of Malformation & \multicolumn{2}{|c|}{$\begin{array}{c}\text { Rate per 1,000 } \\
\text { Singleton } \\
\text { Births }\end{array}$} \\
\hline $\begin{array}{l}\text { Central nervous system } \\
\text { Anencephaly } \\
\text { Spina bifida without anencephaly } \\
\text { Other } \\
\text { Total }\end{array}$ & $\begin{array}{l}3 \cdot 09 \\
3 \cdot 92 \\
1 \cdot 16 \\
8 \cdot 17\end{array}$ & $\begin{array}{l}(281) \\
(356) \\
(106) \\
(743)\end{array}$ \\
\hline $\begin{array}{l}\text { Heart and great vessels } \\
\text { Septal defect alone } \\
\text { Patent ductus alone } \\
\text { Other } \\
\text { Total }\end{array}$ & $\begin{array}{l}0 \cdot 80 \\
0 \cdot 42 \\
3 \cdot 16 \\
4 \cdot 38\end{array}$ & $\begin{array}{r}(73) \\
(38) \\
(287) \\
(398)\end{array}$ \\
\hline $\begin{array}{l}\text { Alimentary system } \\
\text { Cleft lip and/or cleft palate } \\
\text { Atresia } 1 \\
\text { Pyloric stenosis } \\
\text { Other } \\
\text { Total }\end{array}$ & $\begin{array}{l}2 \cdot 06 \\
1.92 \\
2 \cdot 16 \\
1 \cdot 04 \\
6 \cdot 28\end{array}$ & $\begin{array}{r}(187) \\
(93) \\
(196) \\
(95) \\
(571)\end{array}$ \\
\hline $\begin{array}{l}\text { Limbs and skeletal system (without spina bifida) } \\
\text { Dislocation of hip } \\
\text { Talipes } \\
\text { Other } \\
\text { Total }\end{array}$ & $\begin{array}{l}0 \cdot 85 \\
3 \cdot 42 \\
4 \cdot 16 \\
8 \cdot 42\end{array}$ & $\begin{array}{l}(77) \\
(311) \\
(378) \\
(766)\end{array}$ \\
\hline $\begin{array}{l}\text { Miscellaneous systems } \\
\text { Down's syndrome } \\
\text { Urogenital } \\
\text { Skin defect } \\
\text { Other } \\
\text { Total }\end{array}$ & $\begin{array}{r}0.99 \\
2 \cdot 66 \\
4 \cdot 05 \\
4 \cdot 90 \\
12 \cdot 60\end{array}$ & $\begin{array}{r}(90) \\
(242) \\
(368) \\
(446) \\
(1,146)\end{array}$ \\
\hline
\end{tabular}

${ }^{1}$ Includes all atresias from oesophagus to anus 
some of the more important congenital defects in our population of singleton births. And here the problem of taxonomy has to be faced. It has two aspects. First, there is no generally accepted definition of what should be included and what excluded from a survey of congenital defects. This problem has been discussed by McKeown and Record (1960) in relation to the on-going survey of defects in Birmingham. They decided, for reasons which they explain, to include as a congenital malformation any 'macroscopical abnormality of structure attributed to faulty development and present at birth'. This definition excludes metabolic disorders, such as phenylketonuria, and fibrocystic disease of the pancreas. In the Birmingham study herniae and tumours (including naevi) were also excluded. In our study we have included all defects notified to us (macroscopic, microscopic, metabolic, and tumours) that were thought to have been present at birth. Our only exclusions are umbilical and inguinal herniae.

Second, and more difficult, is the problem of classification (discussed by Edwards, Leck, and Record (1964), and by Stevenson, Johnston, Stewart, and Golding (1966)). For this also there is no generally accepted solution. The difficulty is, essentially, that because the aetiology of the great majority of defects is unknown, some arbitrary classification, usually by anatomical system, has to be devised, but multiple defects are common (Table III) and these often cut across the anatomical systems. In our study we have accepted the classification of defects used by the Ministry of Health since 1964 (see Appendix, p. 63). This implies that in any presentation of incidence classified by anatomical system, some malformed infants with defects attributed to more than one system are inevitably included more than once.

Because of the difficulties and disagreements

TABLE VII

INCIDENCE OF CERTAIN CONGENITAL DEFECTS IN SOUTH WALES COMPARED WITH BIRMINGHAM AND LIVERPOOL

\begin{tabular}{|c|c|c|c|}
\hline Type of Defect & $\begin{array}{c}\text { S. Wales } \\
\text { 1964-6 } \\
\text { (90,921 } \\
\text { singleton } \\
\text { births) }\end{array}$ & $\begin{array}{c}\text { Birming- } \\
\text { ham } \\
1950-4 \\
\text { (94,474 } \\
\text { total } \\
\text { births) }\end{array}$ & $\begin{array}{c}\text { Liver- } \\
\text { pool } \\
1960-4 \\
\text { (91,176 } \\
\text { total } \\
\text { births) }\end{array}$ \\
\hline $\begin{array}{l}\text { Anencephalus } \\
\text { Spina bifida (without anence- } \\
\text { phalus) } \\
\text { Hydrocephalus (without spina } \\
\text { bifida) } \\
\text { Down's syndrome } \\
\text { Cardiac malformation } \\
\text { Cleft lip and/or palate } \\
\text { Talipes } \\
\text { Dislocation of hip }\end{array}$ & $\begin{array}{l}3.09 \\
3.92 \\
0.90 \\
0.99 \\
4.38 \\
2.06 \\
3.42 \\
0.85\end{array}$ & $\begin{array}{l}2 \cdot 01 \\
2 \cdot 18 \\
1 \cdot 39 \\
1 \cdot 61 \\
4 \cdot 23 \\
1.98 \\
5 \cdot 72 \\
0.91\end{array}$ & $\begin{array}{l}3 \cdot 14 \\
3 \cdot 36 \\
0 \cdot 55 \\
1 \cdot 43 \\
5 \cdot 03 \\
1 \cdot 54 \\
2 \cdot 65 \\
0 \cdot 67\end{array}$ \\
\hline
\end{tabular}

about definition and classification, comparisor 8 between the incidence of defects or of malformeed infants in different areas may have little or no meas ing. With the reservation that even the compariso of the incidence of specific defects in different areas is of limited value, we compare in Table VII the in $n^{+}$ cidence of certain defects in our two-year follow-u黑 in South Wales with their incidence at five-yeage follow-up in Birmingham (Leck et al. 1968) and Liverpool (Smithells, 1968). With a few interesting exceptions there is good agreement. The inciden both of anencephalus and of spina bifida without anencephalus is substantially higher in South Wales than in Birmingham. The incidence of neural tube defects is already known to be exceptionally high parts of South Wales (Laurence, Carter, and Davis 1968) and the reasons for this will be explored in is later publication.

\section{SUMmaRY}

Data have been collected about all the infants bor? in the three years 1964-6 to women resident in the counties of Glamorgan and Monmouthshire (an the four county boroughs within their boundaries? and about all congenital defects noted in those infants.

The methods by which the defects were ident通ed are described and the incidence of certain of ân defects is presented and compared with the reported incidence of the same defects in Birmingham and Liverpool.

Over the three years of the investigation 92,982 infants were born, 90,921 the outcome of singletor and 2,061 of multiple pregnancies. Among the singleton infants, 3,242 were reported to have cont genital defects $(35.7$ per 1,000 total births) in two-year follow-up.

The incidence of neural tube defects is higher i in South Wales than in Liverpool and substantial higher than in Birmingham.

We acknowledge with gratitude the generous gran from the Association for the Aid of Crippled Childrew, New York, which made this investigation possible. It is with pleasure that we acknowledge our indebtedness the Medical Officers of Health of Cardiff, Merthyr Tydfit; Newport, Swansea, Glamorgan, and Monmouthshirfe, for their interest and co-operation and to the many consultant obstetricians, paediatricians, pathologist dermatologists, and orthopaedic, plastic, and ophthalmis surgeons who have notified and continue to notify to us the names of infants in our birth population who haye come to their attention with congenital defects. We are most grateful to Mrs. S. Lloyd for programming the material for computerization and to Dr. J. Howlett and Mrs. J. Lay of the Atlas Computer Laboratory, Chilton Berks, for the help they and their staff have always givę us. 


\section{REFERENCES}

EDWARDS, J. H., LeCK, I., and ReCord, R. G. (1964). A classification of malformations. Acta genet. (Basel), $14,76$.

HaLE, F. (1933). Pigs born without eyeballs. J. Hered., 24, 105.

laurence, K. M., Carter, C. O., and David, P. A. (1968). Major central nervous system malformations in South Wales 1. Incidence, local variations and geographical factors. Brit. J. prev. soc. Med., 22, 146.

LECK, I., and RECORD, R. G. (1963). Sources of variation in the reporting of malformations. Develop. Med. Child. Neurol, 5, 364.

- _ McKeown, T., and Edwards, J. H. (1968). The incidence of malformations in Birmingham, England, 1950-1959. Teratology, 1, 263.

McKeown, T., and ReCord, R. G. (1960). Malformation in a population observed for five years after birth. In Ciba Foundation Symposium on Congenital Malformations, edited by G. E. W. Wolstenholme and C. M. O’Connor, pp. 2-21. Churchill, London.

Smithells, R. W. (1962). The Liverpool congenital abnormalities registry. Develop Med. Child Neurol., 4, 320.

- (1968). Incidence of congenital abnormalities in Liverpool 1960-64. Brit. J. prev. soc. Med., 22, 36.

Stevenson, A. C., Johnston, H. A., Stewart, M. I. P., and GoldiNG, D. R. (1966). Congenital Malformations: A Report of a Study of a Series of Consecutive Births in 24 Centres. Bull. Wld. Hlth Org., Suppl. to Vol. 34.

\section{APPENDIX}

Ministry of Health Classification of Congenital MALFORMATIONS

0 Central Nervous System

.0 Defects of brain NOS.

.1 Anencephalus

.2 Encephalocele

.3 Arnold-Chiari malformation

.4 Hydrocephalus

.5 Microcephalus

.6 Other defects of brain

.7 Defects of spinal cord NOS.

.8 Spina bifida

.9 Other defects of spinal cord

1 EyE, EAR

.0 Defects of eye NOS.

.1 Anophthalmos, microphthalmos

.2 Buphthalmos

.3 Cataract

.4 Corneal opacity

.5 Other defects of eye

.6 Defects of ear NOS.

.7 Defects of ear causing impairment of hearing

.8 Accessory auricle

.9 Other defects of ear

2 Alimentary System

.0 Defects of alimentary system NOS.

.1 Cleft lip
.2 Cleft palate

.3 Hiatus hernia

.4 Tracheo-oesophageal fistula, oesophageal atresia, and stenosis

.5 Intestinal atresia

.6 Hirschsprung's disease

.7 Rectal and anal atresia

.8 Defects of liver and biliary tracts

.9 Other defects of alimentary system

3 Heart and Great Vessels

.0 Congenital heart disease NOS.

.1 Common truncus

.2 Tetralogy of Fallot

.3 Transposition of great vessels

.4 Defects of aortic arch

.5 Interatrial septal defect, persistent foramen ovale

.6 Interventricular septal defect

.7 Persistent ductus arteriosus

.8 Endocardial fibroelastosis

.9 Other defects of heart and great vessels

4 ResPiratory SyStem

.0 Defects of respiratory system NOS.

.1 Defects of nose (arhinia, choanal atresia or stenosis)

.2 Defects of larynx

.3 Defects of trachea

.4 Defects of bronchus

.5 Defects of lung

.6 Defects of pleura

7 Defects of diaphragm

.8 Defects of mediastinum

.9 Other defects of respiratory system

5 UROgenital System

.0 Defects of urogenital system NOS.

.1 Renal agenesis

.2 Polycystic kidney, all forms

.3 Obstructive defects of urinary tract (hydronephrosis, hydroureter)

.4 Other defects of kidney and ureter

.5 Other defects of bladder and urethra

.6 Hypospadias, epispadias

.7 Other defects of male genitalia

.8 Defects of female genitalia (includes female pseudo-hermaphroditism)

.9 Indeterminate sex (includes true hermaphroditism)

6 LIMBS

.0 Defects of upper limb NOS.

.1 Defects of lower limb NOS.

.2 Reduction deformities (amelia, hemimelia, phocomelia, etc.)

.3 Polydactyly

.4 Syndactyly

.5 Dislocation of hip

.6 Talipes

.7 Other defects of shoulder girdle, upper arm, and forearm

.8 Other defects' of hand

.9 Other defects, of pelvic girdle and lower limb 
7 Other Skeletal

.0 Defects of skeleton NOS.

.1 Defects of skull and face

.2 Spinal curvature, scoliosis, lordosis

.3 Other defects of spine

.4 Defects of ribs and sternum

.5 Chondrodystrophy

.6 Osteogenesis imperfecta

.9 Other generalized defects of skeleton (including arachnodactyly)

8 OTHER SYSTEMS

.0 Branchial cleft, cyst or fistula: preauricular sinus

.1 Other defects of face and neck

.2 Defects of muscles

.3 Vascular defects of skin, subcutaneous tissues, and mucous membranes (including lymphatic defects)

.4 Other defects of skin (including ichthyosis congenita)
.5 Defects of hair, nails, and teeth

6 Defects of peripheral vascular system other than 8.3 (including arteriovenous aneurysm, etc.)

7 Defects of spleen

.8 Defects of endocrine glands

.9 Exomphalos, omphalocele

9 Other Malformations

.0 Congenital malformations NOS.

.1 Multiple malformations NOS.

.2 Cyclops

.3 Other monster

.4 Conjoined twins

.5 Situs inversus

.6 Mongolism

.7 Other chromosomal syndromes

.8 Other specific syndromes

.9 Other 